\title{
MODELS OF THE LEGAL CONSTRUCT OF CONSENT FOR POST MORTEM ORGAN TRANSPLANTATION ILLUSTRATED BY THE EXAMPLE OF POLAND, NORWAY AND USA
}

\author{
Emilia Sarnacka*
}

\begin{abstract}
Each country which allows for organ transplantation developed legal regulations concerning the related procedure the objective of which is to both ensure the safety of the procedure and to prevent trafficking in human organs. There are however substantial differences between the solutions adopted by particular legislators.

The most commonly used models include the legal construct of explicit consent (represented by Norwegian legislator) and presumed consent (adopted in Poland). A half-way model described as a bridge between those two constructs is the gift law construct adopted in the USA.

The analysis of particular legal regulations related to transplantology may have an impact on amendments to Polish legislation aiming at an increase in the number of organ transplants.
\end{abstract}

Key words: transplantation, gift law, medical law

* PhD, Medical University of Bialystok, Department of Medical Law and Ethics. Centre of Postgraduate Medical Education, School of Public Health, emilia.sarnacka@umb. edu.pl. 


\section{INTRODUCTION}

Transplantation, from Latin transplantare - uproot and plant, replant ${ }^{1}$ is "a surgical removal of a tissue or organ from one place to replace a missing, damaged or defective tissue or organ within one organism or with the participation of two organisms" 2 . According to World Health Organization transplantation is the "transfer (engraftment) of human cells, tissues or organs from a donor to a recipient with the aim of restoring function(s) in the body"3.

Medical literature provides for a few criteria applied in the categorization of transplantation ${ }^{4}$. When taking into account the donor-recipient genetic similarity the following types may be distinguished: autografts (within one organism), isografts (transplant form a donor to a genetically identical recipient e.g. monozygotic twins), allografts (between two genetically non-identical members of the same species), and xenograft (between members of different species) $)^{5}$. As for classification by the site of explantation and implantation there are: isotopic transplantations (the tissue and site of transplantation correspond), orthotopic transplantations (there is an anatomic correspondence of the transplantation site yet the histological correspondence is not required), and heterotopic transplantations (the anatomic position of the transplanted organ in the recipient's body does

${ }^{1}$ Elwira Olejniczak, Beata Kukiela, "Media image of ex mortuo transplantation and legal regulations", Folia Linguistica, (46) 2012: 86.

${ }^{2}$ Dictionary of Contemporary Polish Language vol. II, Wilga Publishing house, Warsaw 2000, p. 436.

${ }^{3}$ WHO, Global Glossary on Donation and Transplantation, Geneva 2009.

${ }^{4}$ More on the subject: Juliusz Duda, "Medical Transplantation Issue Viewed from the Civil-Law Perspective”, Warsaw: Wolters Kluwer, 2011, pp. 20-21. Ewa Monika GuzikMakaruk, "Organ, tissue, and cells transplant in legal and criminological terms", Białystok: Temida 2, 2008, pp. 29-32, Maria Nowacka, "Ethics of Transplantation", In: Bioethics, ed. Joanna Różyńska, Weronika Chańska, Warsaw: Wolters Kluwer, 2013, pp. 221225. Rafał Kubiak, "Medical law”, Warsaw: C.H. Beck, 2010, p. 475.

${ }^{5}$ More on the subject: Małgorzata Paszkowska, "Legal admissibility of transplantation as a method of treatment", Medical Review of Rzeszów University and National Medicines Institute in Warsaw, 2011, No 4, p. 546. 
not correspond to its position in the donor's body) ${ }^{6}$. There is additionally a distinction made between biovital transplantations (transplant of a living organ which saves life) and biostatic transplantation (transplant of not living tissues or cells which foster recovery) ${ }^{7}$. Assuming the vital condition of the donor is the criterion, one may distinguish: ex vivo transplants (from a living donor) and ex mortuo (from a deceased donor) ${ }^{8}$.

"Solid organ transplantation is a treatment option to improve the quality of life of people at any age suffering from irreversible and end-stage chronic conditions"?

Transplantology as a life-saving method is an exceptional area subject to analysis. It is intrinsically linked with the development of medicine and the more and more innovative treatment methods. Nevertheless, the development is also influenced by other factors which are not related to medical sciences. These include cultural factors, the degree to which society developed as civil society ${ }^{10}$, influence of religions and religious associations, and the trust the society has in medical personnel, especially in doctors

${ }^{6}$ Ewa Monika Guzik-Makaruk, Organ, tissue, and cells transplant in legal and criminological terms, Białystok: Temida 2, 2008, p. 31.

${ }^{7}$ According to: Juliusz Duda, "Medical Transplantation Issue Viewed from the CivilLaw Perspective”, Warsaw: Wolters Kluwer, 2011, 21 and literature quoted therein.

${ }^{8}$ Ibidem.

${ }_{9}^{9}$ Karina Dal Sasso Mendes, Bartira de Aguiar Roza, Sayonara de Fatima Faria Barbosa, Janine Schrimer, Cristina Maria Galvao, "Organ and tissue transplantation: responsibilities of nurses”, Text Context Nursing, 21/4 (2012): 946.

${ }^{10}$ The notion of civil society is related to English social thought represented by John Locke and David Hume. A contemporary community may be viewed as civil society if it has the following features: sovereign body is the people exercising authority through the citizens, authority is exercised on the basis of codified law, legal system safeguarding citizens' rights and freedoms, institutions ensuring the law is observed, citizens' participation in social life is guaranteed, according to: Henryk Sasinowski, "Civil society and its role in the creation of democracy", Economy and Management, 1(2012): 33; more on civil society in: Kamil Czyż, "Civil society as the prerequisite of democratic state", ZNZE WSIiZ, 1/3(2007): 175-197; Katarzyna Maj-Waśniowska, "Dilemmas of civil society in Poland", Research papers of Wrocław University of Economics, 404(2015): 170-189; Jerzy W. Gałkowski, Łukasz Kanafa, "Civil Society and Morality", Annales. Ethics in Economic Life, 13(2010): 69-75. 
as representatives of profession of public trust ${ }^{11}$. One of the 'non-medical' factors playing a crucial role is the provisions of law concerning the proper use of transplantology as a treatment method i.e. those which establish the criteria of cell, tissue or organ extraction admissibility, regulate the procedure of granting a consent for a transplant, and provide for possible penalties in the case of breach of applicable regulations.

Transplantation medicine could not function without appropriate legal regulations. All countries where transplantations are performed have developed relevant legislation ${ }^{12}$. The provisions of law ensure the lawfulness of extracting organs from living and deceased donors, found transparent rules related to the transplantation procedure and its safety, and also include regulations on penalizing the attempts to commercialize transplantations ${ }^{13}$. Proper stance of the legislator, particularly conspicuous in legal regulations safeguarding the protection of donors' and their relatives' personal rights, may have a positive impact on the development of transplantology and earning social trust in the matter of organ procurement. On the other hand, the absence of precise regulations related to, for instance, penalization of accepting financial benefits for intermediation in transplantation, may result in the possibility of abuse in the form of organ

${ }^{11}$ Profession of public trust is a particular Polish notion unknown in other countries, neither in Europe nor in the USA. The institution of professions of public trust has been introduced to the Polish legal system under Article 17 of the Constitution of the Republic of Poland which imposes the requirement of establishing professional self-government authorities. The catalogue of professions enjoying this special status includes those the performance of which is related to tasks of particular nature from the perspective of public activities and care for public interest. More on the subject: Paweł Antkowiak, "Polish and European standards of performing independent professions", Politology Review, 1(2013): 135; Andrzej Krasnowolski, "Professions of Public Trust Regulated Professions and Independent Professions. Origins, functioning and current problems", Warsaw: Chancellery of the Senate, Thematic Papers OT-625, 2013, p. 3.

12 Wojciech Rowiński, "Legal, ethical, social, and organisational aspects of organ transplantation in Poland (Data as of the end of 2009)", In: Public Health. Selected Aspects. Vol. II, ed. Janusz Opolski, Warsaw: Medical Postgraduate Training Centre, 2011, p. 52.

${ }^{13}$ Ibidem. 
trafficking ${ }^{14}$ which in turn will trigger a drop in public trust towards the procedure and thus in the number of potential donors.

Transplantation constitutes the subject matter of regulations set forth by numerous international organizations ${ }^{15}$. Particular attention should be drawn to the activities undertaken by the World Health Organization which in cooperation with the Organizacion Nacional de Transplantes decided to unify the related terminology and drew up 'Global Glossary on Donation and Transplantation'16. From among 72 unified definitions the following deserve particular attention: : transplantation (The transfer (engraftment) of human cells, tissues or organs from a donor to a recipient with the aim of restoring function(s) in the body. When transplantation is performed between different species, e.g. animal to human, it is named Xenotransplantation), donor (a human being, living or deceased, who is a source of cells, tissues or organs for the purpose of transplantation), organ (Differentiated and vital part of the human body, formed by different tissues, that maintains its structure, vascularisation and capacity to develop physiological functions with an important level of autonomy), potential deceased donor (Deceased person without absolute medical contraindications with brain death or cardiac death diagnosis initiated or completed $)^{17}$.

Moreover, during the Sixty-third. World Health Assembly in 2010 WHO endorsed 11 guiding principles which should constitute the foun-

${ }^{14}$ More on the subject of organ trafficking in: Michał Boczek, "Transplantation of business", In: New medical procedures vs law, ed. Jacek Sobczak, Magdalena Reshef, Toruń: Adam Marszałek Publishing House, 2016, pp. 297-307. Szymon Buczyński, Paweł Snopek, "Criminal aspects of illicit trafficking in human organ, tissues and cells", Hygeia Public Health, 49/2(2013): 229-234. Anna Głogowska, "Trafficking in persons for the purpose of organ removal from an international legal perspective", Białostockie studia Prawnicze, 13(2013): 137-145. Grzegorz Hołub, "About two ways of acquiring organs for transplantation”, Studia Gdańskie, XXV(2009): 129-146.

${ }^{15}$ More on the subject: Paulina Konarska, "Post mortem extraction and transplantation of organs, tissues, and cells in Asia exemplified by Singapore and India - selected aspects", Studies in Law: Research Papers, 1/18(2016): 142-144.

${ }^{16}$ The document was drawn up in Geneva in 2009. It is explained in the introduction that the authors' intention was to collect existing definitions rather than to create new ones. The document is available at the WHO website: http://www.who.int/transplantation/activities/GlobalGlossaryonDonation Transplantation.pdf?ua=1.

17 Ibidem. 
dation of legal regulations concerning transplantology ${ }^{18}$. In accordance with the first principle cells, tissues and organs may be removed from the bodies of deceased persons for the purpose of transplantation if any consent required by law is obtained or there is no reason to believe that the deceased person objected to such removal. Apparently, WHO does not take a stance in the matter of the form of the consent for organ procurement. It admits both express and implied consent. In the light of the second principle physicians determining that a potential donor has died should not be directly involved in cell, tissue or organ removal from the donor or subsequent transplantation procedures. The third principle aims at undertaking steps with a view to developing transplantations from deceased donors with the observance of legal and logical rules. Donation from deceased persons should be developed to its maximum therapeutic potential, but adult living persons should be given the possibility to donate organs as permitted by domestic regulations. In general, however, living donors should be genetically, legally or emotionally related to their recipients. The fourth principle imposes the requirement of protecting minor donors and those who are unable to express their consent by introducing a ban on removing cells, tissues or organs except for narrow exceptions provided for by domestic law. Furthermore, specific measures should be in place to protect the minor and, wherever possible the minor's assent should be obtained before donation. This principle allows for a minor's participation in familial donation of regenerative cells provided that a therapeutically comparable adult donor is not available and kidney transplants between identical twins. The principle embraces the protection of minors against the function of the so called 'biological resupply vehicle' 19 .

WHO places particular emphasis on preventing organ trafficking. The fifth principle stipulates that the donation should be donated freely, without any monetary payment or other reward of monetary value. Fur-

${ }_{18}$ WHO Guiding Principles On Human Cell, Tissue And Organ Transplantation available at the WHO website: http://www.who.int/transplantation/Guiding_PrinciplesTransplantation_WHA63.22en.pdf?ua=1.

${ }^{19}$ More on the issue of the so called 'baby-biological resupply vehicle' in: Joanna Haberko, "Applying techniques of medically supported procreation not only for parental purposes. The problem of 'baby-biological resupply vehicle"', Wokanda Medyczna, 4(2012): 31-43. 
thermore, it introduces a ban on selling cells, tissue or organs, yet the prohibition does not preclude reimbursing reasonable and verifiable expenses incurred by the donor, including loss of income, or paying the costs of recovering. The next principle allows for promotion of altruistic donation of human cells, tissues or organs, however it also imposes an obligation of introducing appropriate domestic regulations prohibiting acquisition of financial benefits for brokering. The next two principles state that physicians and other health professionals should not engage in transplantation procedures, and that health insurers and other payers should not cover such procedures. It does not mean that it is prohibited for them to participate in the removal and implantation of an organ, but solely the ban on participation in administrative activities, in particular in paid consultations with the donor and their family the objective of which is to obtain their consent to the donation.

Within the scope of the subject matter discussed, WHO actions are concurrent with the European Council actions ${ }^{20}$, in particular with the provisions of the Additional Protocol to the Convention on Human Rights and Biomedicine concerning Transplantation of Organs and Tissues of Human Origin (hereinafter: Additional Protocol) ${ }^{21}$ and adopted in

${ }^{20}$ Andrzej Rzepliński, "Legal limits of human organ and tissue transplantation admissibility under the provisions of the European Council", Prawo i Medycyna, 2(12 vol. 4) (2002).

${ }^{21}$ Protocol available at the European Council website: http://www.coe.int/en/web/ conventions/full-list/-/conventions/treaty/186. The Protocol was opened for signature on $24^{\text {th }}$ January 2002 in Strasburg and signed by the following countries: Bulgaria, Croatia, Estonia, Finland, France, Georgia, Greece, Hungary, Iceland, Italy, Luxemburg, Montenegro, Holland, Portugal, The Republic of Moldova, Romania, Serbia, Slovenia, Spain, Switzerland, The Republic of Macedonia and Ukraine. More on the Additional Protocol see: Additional Protocol concerning Transplantation of Organs and Tissues of Human Origin In: International Bioethics Standards. Documents and judicial practice, eds. Tadeusz Jasudowicz, Jakub Czepek, Julia Kapelańska - Pręgowska, Warsaw: Wolters Kluwer, 2014, pp. 60-68; see: Emilia Sarnacka, "Legal aspects of transplantation”, In: Transplantology and transplantological nursing, eds. Hanna Rolka, Beata Kowalewska, Barbara Jankowiak, Elżbieta Krajewska - Kułak, Warsaw: PZWL, 2016, pp. 80-84; Andrzej Rzepliński, "Legal limits of human organ and tissue transplantation admissibility under the provisions of the European Council”, Prawo i Medycyna, 2/12 vol. 4 (2002). 
Santiago de Compostela in 2015 Council of Europe Convention against trafficking in human organ ${ }^{22}$.

Principles number nine and eleven impose the transparency requirement on the transplantation procedure. The allocation of organs, cells and tissues should be guided by clinical criteria and ethical norms, not financial considerations. Allocation rules, defined by appropriately constituted committees, should be equitable, externally justified, and transparent. By analogy, The organization and execution of donation and transplantation activities, as well as their clinical results, must be transparent and open to scrutiny, while ensuring that the personal anonymity and privacy of donors and recipients are always protected. The transparency of allocation jest also a guideline laid down by the European Council in the above-mentioned Additional Protocol.

Last but not least of the principles in question relates solely to ex vivo donation. It states that the long-term outcomes of cell, tissue and organ donation and transplantation should be assessed for the living donor as well as the recipient. It is intrinsically related to ensuring high-quality, safe and efficacious procedures.

To conclude the above, transplantation constitutes a particular field of treatment activities and requires special analysis of the legislators with a view to establishing standards which are compliant with international legal regulations and adequate for the characteristics of a given society. An analysis of the Resolution of the Council of Ministers number 164/10 of $12^{\text {th }}$ October 2010 on establishing a long-term programme for the years 2011-2020 under the name 'National Program for the Development of Transplantation Medicine ${ }^{23}$ constituted a trigger for the present study. The programme was based on 9 particular goals: increasing the availabil-

${ }^{22}$ The Convention available at the European Council website: https:/www.coe.int/ en/web/conventions/full-list/-/conventions/treaty/216. The Convention has been signed by 18 countries: Albania (including ratification), Austria, Belgium, The Czech Republic, Greece, Ireland, Italy, Latvia, Luxemburg, Norway, Poland, Portugal, The Republic of Moldova (including ratification), Russian Federation, Spain, Switzerland, Turkey and The United Kingdom of Great Britain and Ireland. More on the Convention see: E. Sarnacka, "Legal aspects ...", op. cit., pp. 84-88.

${ }^{23}$ Resolution under Article 136 Section 2 of the Act of 27th August 2009 on Public Finances (i.e. Journal of Laws of 2016 item 1870). 
ity of organ transplant treatment by an increase of the number of organ transplants from deceased donors by at least $100 \%$ when compared to the number in 200924; augmenting the number of potential unrelated donors of bone-marrow by at least $300 \%$ when compared to the number of potential unrelated donors of bone-marrow in Polish registers by the end of 2009 as well as the development of public and non-public registers of unrelated donors of umbilical cord blood; scaling up the number of kidney transplant from living donors by at least $500 \%$ in comparison to the number in 2009; developing an organisational system of coordinators for cell, tissue and organ procurement and transplant from deceased donors; improving the infrastructure and modernising the treatment facilities performing organ, tissue and cell transplants, tissue and cell banks and medical diagnostic laboratories; implementing new types of organ, tissue and cell transplants and developing programmes for transplants in groups of high-risk recipients; developing and improving monitoring, supervision and quality control systems for transplantology aiming at the improvement of transplantation results in particular by means of continuation of transplantation registers development; epidemiologic assessment of the needs in the scope of particular organs transplants and hematopoietic cells transplant as well as performing economic analysis of the organ and hematopoietic cells transplants costs in comparison to traditional treatment taking into account the treatment results and the social effects; training professionals whose activities directly influence the quality of cells, tissue or organs or the safety of donors and recipients.

One of the key objectives of the programme is a substantial increase in the number of post mortem transplants. The crucial issue when it comes to the number of transplants from deceased donors is the consent to extract biological material. In view of the foregoing, the related legislation seems worth analysing in order to assess the need for legislative changes.

As far as the post mortem transplants are concerned, legal regulations constitute "a reflection of a particular for a given culture outlook on human death (allowing for extraction after circulatory arrest or pronouncement of

${ }^{24}$ In 2009 the number of deceased organ donors was 548 (actual donors - 420), whereas the number of organs transplanted reached 1077, source: poltransplant.org.pl [date of access: 27.07.2017]. 
brain death), stipulate the rules and manners of recognising death (most commonly under a committee supervision) ensuring that the physician confirming the death is excluded from the participation in the procurement or transplant surgery, and lay down the rules concerning authorisation (manner of consenting) enabling the extraction of an organ which safeguards the observance of the deceased person's will in case they did not wish their organs were used for transplantation" 25 .

In principle, in the doctrine there are two models of the construct of consent for organ transplantation from a deceased donor, namely the opt in and opt out models ${ }^{26}$. The former requires an express consent for the extraction of biological material, whereas the latter is based upon the so-called implied consent which assumes that the absence of express objection during the donor's lifetime is tantamount to consent for extraction ${ }^{27}$. The opt in model is represented by the legislation in Great Britain, Denmark, Greece, Norway, Sweden, and Switzerland, however, Denmark and Great Britain require additionally the family's consent. The construct of implied consent has been used by the legislators in Austria, Belgium, Fin-

${ }^{25}$ Wojciech Rowiński, "Legal, ethical, social, and organisational aspects of organ transplantation in Poland (Data as of the end of 2009)", In: Public Health. Selected Aspects. Vol. II, ed. Janusz Opolski, Warsaw: Medical Postgraduate Training Centre, 2011, p. 52.

${ }^{26}$ The third model mentioned in literature is the state of necessity which assumes that "in relations to the proportion of goods, the good being saved and the good being sacrificed, there is a possibility of finding that life and health of the living person is a greater good and therefore scarifying the good in the form of the infringement of the deceased person's body is admissible, even in spite of the donor's objection expressed earlier", Ewa Monika Guzik-Makaruk, "Organ, tissue, and cells transplant in legal and criminological terms”, Białystok: Temida 2, 2008, p. 35.

${ }^{27}$ More on models of deciding on extracting material from deceased donors see: Rafał Kubiak, "Medical law", Warsaw: C.H. Beck, 2010, pp. 483-487. Mirosław Nestorowicz, "Medical Law", Edition VIII, Toruń 2007, p. 293, Ewa Monika Guzik-Makaruk, "Organ, tissue, and cells transplant in legal and criminological terms", Białystok: Temida 2, 2008, pp. 33-37. Joanna Haberko, "A few comments on ex mortuo tissue, cell, and organ extraction from foreign donors", Medyczna Wokanda, 3(2011): 102; Małgorzata Paszkowska, "Legal admissibility of transplantation as a method of treatment," Review of Rzeszów University and National Medicines Institute in Warsaw, 4(2011): 546; Lexicon of Medical Law. 100 basic terms, ed. Adam Górski, Warsaw: C.H. Beck, 2012, p. 237. 
land, France, Spain, Portugal, Russia, and Poland ${ }^{28}$. Contrary to European regulations, the United States of America developed individual model of consent for post mortem organ extraction, namely gift law which combines the above-mentioned models as it allows for both, making a declaration of will during the donor's lifetime and, in the absence of such, consent given by the family members.

As it has already been stated, Polish legislator adopted the implied consent model under the assumption that this legal construct facilitates organ procurement from deceased donors and thus boosts the number of transplantations. Practice has shown that physicians still ask the family of the deceased for consent and in the case of refusal, they decide not to commence the transplantation procedure ${ }^{29}$. The attitude is caused by fear of court suits in which the family of the deceased will testify that during their lifetime, the deceased person was against organ procuremen $t^{30}$. One should also agree with the view expressed in the doctrine stating that "resistance resulting from the state of awareness constitute one of the most significant

${ }^{28}$ Maria Nowacka, "Ethics of Transplantation", In: Bioethics, ed. Joanna Różyńska, Weronika Chańska, Warsaw: Wolters Kluwer, 2013, pp. 221-225. Rafał Kubiak, "Medical law", Warsaw: C.H. Beck, 2010, p. 223.

${ }^{29}$ According to a study by Public Opinion Research Centre (CBOS) conducted in 2016, a mere 20\% has knowledge that in Poland applies the implied consent model, yet the number increased by $6 \%$ in comparison to 2012, as in: Attitudes to Organ Transplantation. Communication on Research number 119/2016, CBOS, Warsaw, 2016. Research conducted in 2002 showed that $76 \%$ of Poles believe that doctors have the obligation to ask the family of the deceased patient for consent to extract organs, in spite of the fact that such consent is not required by law. Only $24 \%$ of the persons surveyed think that eventually these are legal regulations which should be decisive in relation to organ extraction, as in: Alina Kośmider-Cichomska, "Attitudes to Organ Transplantation. Report on Research", Warsaw: Ipsos-Demosop for "United for Transplantation" Foundation, 2002, p. 11. See also Maria Nowacka, "Ethics of Transplantation", In: Bioethics, ed. Joanna Różyńska, Weronika Chańska, Warsaw: Wolters Kluwer, 2013, pp. 223-224, Joanna Jurek, Martyna Chwal, Bernadetta Janusz, Bogdan de Barbaro, "Organ Extraction post mortem: psychological situation of the family, cultural context, the role of professionals (Family context of decisions on the deceased relative's organ donation. Research review)", Psychoterapia, 4 /159(2011): 51-64.

${ }^{30}$ Ibidem, pp. 223-224. 
obstacles in the development of Polish transplantology. The number of transplantations in Poland is not proportionate to the demand" ${ }^{1}$.

The assumptions made by the legislators that the so-called implied consent construct will increase the number of procurement from deceased donors is not entirely erroneous. The opt out model is used, among other countries, in Spain, Portugal, and Belgium, countries where the number of transplantations is the greatest in whole Europe. According to data included in transplantation newsletter ${ }^{32}$ published by European Directorate for the Quality of Medicines \& Health Care and showing the quantitative differentiation between the European Union Member States and Members of the European Economic Area ${ }^{33}$, the transplantation ratio in Spain in 2015 reached 40.2; in Portugal - 31.0; Belgium - 31.6; in contrast in Poland 13.6 and in Russia - 3.0.

Spanish regulations, which constituted model also for Polish legislators, are frequently recommended as regulations which most effectively influence the number of transplantations. Spanish legislator adopted the so-called implied consent construct, however, before organ procurement hospital coordinator responsible for transplants or a person entrusted with such duties is obligated to undertake steps aiming at establishing the will of the deceased. The required activities include verification whether the donor expressed their will to any of the family members or professionals who treated him in the medical institution (finding whether there exists appropriate annotation in the treatment record made by a professional), verification of documents and personal belongings which the deceased had on them and check whether the donor expressed their will by other means provided for by law ${ }^{34}$. Polish regulation on the subject matter (discussed

${ }^{31}$ Elwira Olejniczak, Beata Kukiela, "Media image of ex mortuo transplantation and legal regulations", Folia Linguistica, (46) 2012: 87.

${ }^{32}$ Newsletter Transplant Vol. 21 No 1 Sept 2016. International figures on donation and transplantation 2014, available at the EDQM website: https:/www.edqm.eu/medias/ fichiers/ newsletter_transplant_vol_20_no_1_sept_2015.pdf .

${ }^{3}$ The report presents statistical analysis on ex mortuo transplants only. It does not include information on transplantations from living donors. Neither does it present data related to body donation for scientific purposes.

${ }^{34}$ Rafał Dubowski, „Non omnis moriar. Organ Procurement for transplant under Spanish law against the background of Polish law", In: Nasciturus pro iam nato habetur: on 
below) is not considerably different from recommended Spanish model, yet there are some dissimilarities ${ }^{35}$.

The aim of the implementation of Spanish model was to boost the number of transplantations in Poland as well. Nevertheless, the aim has not been achieved to the expected extent, in 2015 the number of organ procurement from deceased donors was by 100 organs lower than in the record year $2012^{36}$. It is emphasised in the doctrine that the success of the opt out model is dependent upon social awareness and social support for organ transplantation, including for the implied consent model. Analyses of public opinion have shown that only a small percentage of Polish society has knowledge on the regulations concerning organ procurement when there is no objection ${ }^{37}$. As statistical data demonstrate the choice of legal construct not adjusted to the level of the society's knowledge and attitudes will not trigger off an increase in the number of transplantations ${ }^{38}$. It is

protection of conceived baby and the mother, eds. Jacek Gołaczyński, Jacek Mazurkiewicz, Jarosław Turłukowski, Daniel Karkut, Wrocław: Wydział Prawa, Administracji i Ekonomii Unjiwersytetu Wrocławskiego Oficyna Prawnicza, 2017, p. 194.

${ }^{35}$ More on the subject: Rafał Dubowski, "Non omnis moriar. Organ Procurement for transplant under Spanish law against the background of Polish law", In: Nasciturus pro iam nato habetur: on protection of conceived baby and the mother, eds. Jacek Gołaczyński, Jacek Mazurkiewicz, Jarosław Turłukowski, Daniel Karkut, Wrocław: Wydział Prawa, Administracji i Ekonomii Uniwersytetu Wrocławskiego Oficyna Prawnicza, 2017, pp. 189-209.

${ }^{36} \mathrm{http} / /$ www.rynekzdrowia.pl/Uslugi-medyczne/Transplantologia-w-stagnacji-spada -liczba-przeszczepow-narzadow-w-Polsce, 166901,8.html [date of access: 23.07.2017].

${ }^{37}$ See: Joanna Haberko, Izabela Uhrynowska - Tyszkiewicz, "Act on procurement, storing and transplantation of cells, tissues and organs. Commentary", Warsaw 2014, pp. 68-69 and the literature quoted therein. Krystyna Klimaszewska, Anna Baranowska, "Evaluation of social attitudes towards transplantology", In: Transplantology and transplantological nursing, ed. Hanna Rolka, Beata Kowalewska, Barbara Jankowiak, Elżbieta Krajewska - Kułak, Warsaw: PZWL, 2016, pp. 55-56. Wojciech Boratyński, Paulina Mularczyk, Emilia Sarnacka, "Opinions and attitudes of students of public health to the issues of transplantation medicine", Progress of Health Sciences, Vol 6, No 2 (2016): 145.

${ }^{38}$ Analogical situation may be observed in Singapore where implied consent has been introduced with a view to increase the number of transplantations. Yet the aim has not been achieved. The main reason seems to be the society's reluctance to donate organs post mortem due to the need to maintain the body's "integrity", according to: Paulina Konarska, "Post mortem extraction and transplantation of organs, tissues, and cells in Asia 
therefore worth subjecting the models of consent to assessment in order to consider amendments to Polish transplantation regulations.

The present study aims at analysing models of legal regulations related to post mortem cells, tissue, and organ transplantation. The article concentrates on a description of chosen model on the basis of the legislation of a given country. Assuming that each legislator admitting transplantation as treatment procedure intends to enable the largest number of transplants possible, the solutions adopted are surely worth analysing. The first part of the study focuses on the opt in model adopted in Poland, and following that the opt out model, exemplified by Norwegian legislation, will be discussed. Next, the two models will be confronted with the gift law model used in the United States of America. The choice of each of the countries was not accidental and reflects the dissimilarities with regard to legal regulations (each country represents a different model) and geopolitical situation. Poland as European Union Member State is obligated to implement European regulations in domestic law ${ }^{39}$. For Norway, whose citizens refused to accede to the European Union twice already, the situation relat-

exemplified by Singapore and India - selected aspects", Studies in Law: Research Papers, 1/18(2016): 142-144.149.

${ }^{39}$ See: Directive 2004/23/EC of the European Parliament and of the Council of 31 March 2004 on setting standards of quality and safety for the donation, procurement, testing, processing, preservation, storage and distribution of human tissues and cells (Official Journal L 102,07/04/2004 P. 0048 - 0058); Commission directive 2006/17/EC of the implementing Directive 2004/23/EC of the European Parliament and of the Council as regards certain technical requirements for the donation, procurement and testing of human tissues and cells (Official Journal L 38/40, 09/02/2004 P. 0040 - 0052); Commission directive 2006/86/EC implementing Directive 2004/23/EC of the European Parliament and of the Council as regards traceability requirements, notification of serious adverse reactions and events and certain technical requirements for the coding, processing, preservation, storage and distribution of human tissues and cells (Official Journal L 294 , 25/10/2006 P. 0032 - 0050); Corrigendum to Directive 2010/45/EU of the European Parliament and of the Council of 7 July 2010 on standards of quality and safety of human organs intended for transplantation (Official Journal L 243, 16/09/2010 P. 0068 - 0068); Commission implementing directive 2012/25/EU laying down information procedures for the exchange, between Member States, of human organs intended for transplantation (Official Journal L 275 10/10/2012. 27-32). 
ed to the issue is quite different ${ }^{40}$. The United States has been included as a subject of study as a country using gift law model. Moreover, the choice of the countries was made after taking into consideration the differences in geopolitical situation, historical experience, economic development, and cultural dissimilarities between Europe and North America.

The analysis has been conducted with the use of comparative law method, which by means of comparative analysis of legislative directions and experience of given countries constitutes a basis for further development of the legislation ${ }^{41}$. The following legislative acts have been subject to analysis: Polish Act of $1^{\text {st }}$ July 2005 on procurement, storage and transplantation of cells, tissues and organs (Journal of Laws of 2017 item 1000), Scandinavian act relating to transplantation, hospital autopsies and the donation of bodies etc. (Lov om transplantasjon, sykehusobduksjon og avgivelse av lik m.m.) and American Uniform Anatomical Gift Act ${ }^{42}$. The present analysis embraces only the documents with transplantology as the main subject matter, moreover, documents not having the status of legislative acts remain outside the scope of the present study. The chosen direction of the research intends to demonstrate to what degree transplants required separate regulations, other than those related to standard medical procedures. The solution adopted is a result of the change of the status of

${ }^{40}$ Jonathan Lindsell, “The Norwegian Way. A case study for Britain's future relationship with the EU”, London Civitas: Institute for the Study of Civil Society, 2015, pp. 1-105, Mia Bennett, Icy/Hot: Norway and Finnish Policy toward the European Union, Claremont-UC Undergraduate Research Conference on the European Union, Vol 2008, article 3, DOI: 10.5642/urceu.200801.03 available at: http://scholarship.claremont.edu/ cgi/viewcontent.cgi?article=1014\&context=urceu [date of access: 14.07.2017].

${ }^{41}$ Comparative law method is the main method of legal comparative studies and is divided into methods allowing for the identification of similarities (common legal solutions) or differences demonstrating diversity o institutional solutions in a few legal systems, according to: Aleksander Wróbel, "Comparative law studies in criminal law on the basis of criminal law system in Poland, Ukraine, and Russia - From theory to practice", Scientific Papers of Jagiellonian University PhD Students Association. Social Sciences, 15 (4) (2016): 264.

${ }^{42}$ In all 50 states of the USA one legislative act applies, see more in: Roman Tokarczyk, "Outline of regulation on human organs transplantation", Legal, Economic and Sociological Movement, Year LXII, issue 1 (2000): 20. A unified version of the act after its revision in 2009 was used for the present study. 
transplantation to a treatment method - it is no longer a medical experiment, but constitutes a commonly chosen treatment method falling within the standards of "current medical knowledge" 43 .

In view of the complexity and the great scope of the subject matter, only chosen conditions of post mortem transplantation will be subject to analysis. Key areas of the present study have been determined as follows: stipulating the object of transplantation in a legislative act and the rules on obtaining consent for extraction. Taking into account varying stipulation of the object of transplantation - cells, tissues, organ, biological material - for the purposes of the present analysis the terms "transplant" and "extraction" will refer to the biological material stipulated in the given legislative act. Furthermore, for the purposes of the present study, the legislative acts discussed shall be called transplantation acts/statutes.

\section{OPT OUT MODEL - POLISH REGULATIONS}

Extracting cells, tissues, and organs from deceased donors is regulated in chapter 2 of the Act of $1^{\text {st }}$ July 2005 on procurement, storage, and transplantation of cells, tissues, and organs (Journal of Laws of 2017 item 1000). The object of transplant may be solely cells, tissues, and organs, and the term "cell" refers both to a single cell and to a group of cells not connected by matrix (Article 2 Section 1 Point 23), "tissue" designates each component of human organism made of cells (Article 2 Section 1 Point 46), whereas "organ" means a separate and significant part of human organism made of various tissues and capable of maintaining its structure, vascularisation and capacity to develop physiological functions with significant level of autonomy; a part of an organ is also considered to be an

${ }^{43}$ Joanna Haberko, Izabela Uhrynowska - Tyszkiewicz, "Act on procurement, storing and transplantation of cells, tissues and organs. Commentary”, Warsaw 2014, Wolters Kluwer, p. 20. An analysis of the term „current medical knowledge” see: Joanna Haberko, "Current medical knowledge and using homeopathy", Medyczna Wokanda, 1(2009): 47-59. 
organ if its function is to be used for the same purpose as the entire organ in the human body (Article 2 Section 1 Point 30).

Cells, tissues, and organs may be extracted form a deceased donor after the death has been confirmed ${ }^{44}$. The legislators indicated that extraction, and therefore the transplantation itself as well, is possible only for diagnostic, therapeutic, scientific, and didactic purposes. There are no statutory definitions of the mentioned purposes which was aptly criticised by the doctrine. And even though defining therapeutic and scientific purposes on the basis of the developed scientific standpoints does not raise serious doubts, determining the scope of diagnostic and didactic purpose brings up additional questions. Extracting biological material will not serve the purpose of giving diagnoses, but only the purpose of post mortem findings. Moreover, a question arises whether the legislator within the framework of didactic purpose admitted the use of the material extracted for didactic purposes in non-medical entities ${ }^{45}$.

Polish legislator adopted the construct of the so-called implied consent, characteristic of the opting out model, which assumes there is a presumed consent for extraction of cells, tissues, and organs. What is needed

${ }^{4} 4$ The death is confirmed by a physician or a dentist, yet the death certificate may be issued by a physician only (Article 43 Section 1-2 in relations to Article 3 Section 1 of the Act of 5th December 1995 on the profession of physicians and dentists, Journal of Laws of 2017 item 125). The issue of pronouncing a person dead is an interesting aspect of the subject matter, yet remaining beyond the scope of the present analyses. Polish legislator decided that confirmation of irreversible cessation of brain functions is required to pronounce a person dead, yet the cessation of functions of other systems is not required. The doctrine rightly states that regulating the procedure of death confirmation in an act not having legislative status (Notice of the Minister of Health of $17^{\text {th }}$ July 2007 on the criteria and manner of confirming irreversible cessation of brain functions, M.P. No 46, item 547) is an unconstitutional solution. Not only does it give the Minister of Health interpretative right in the matter of establishing the criteria of death (broadening or narrowing down the interpretation of "cessation of brain functioning), but also the regulation is included in an act which is not the source of law within the meaning of Article 87 of the Constitution; more on the subject in: Rafał Kubiak, "Medical law", Warsaw: C.H. Beck, 2010, p. 479; Ewa Monika Guzik-Makaruk, "Organ, tissue, and cells transplant in legal and criminological terms”, Białystok: Temida 2, 2008, pp. 297-299.

${ }^{45}$ More on the subject of extraction see: Joanna Haberko, Izabela Uhrynowska-Tyszkiewicz, "Act on procurement, storing and transplantation of cells, tissues and organs. Commentary”, Warsaw 2014, Wolters Kluwer, pp. 63-65 and the literature quoted therein. 
to rebut the presumption is the expression of objection during the lifetime in one of the three forms: entry in the central register of objections, written statement with handwritten signature, oral representation made in the presence of at least two witnesses who testify it in writing (Article 6 Section 1). As a consequence of the solution adopted by Polish legislator, a physician having confirmed the death, is obligated to find information in the central register of objections in order to be able to extract an organ for transplantation $^{46}$. In the absence of an entry, the physician should inform themselves whether the patient before death made an oral representation concerning refusal to grant the consent for extracting biological material post mortem. The legislator dis did not precise what kind of activities on the part of the physician may be considered to be the fulfilment of the said obligation, and therefore in which situations the physician shall be legally responsible for negligence. In the absence of precise regulations it should be assumed that the physician's obligation is to consult the patients' relatives whom they contacted before death. Whereas the contact with relatives who were not contacted by the patient in the last days of their life will not be an obligation. It should be remembered that registering the deceased will to the central register of objections is an obligation of the witnesses to the representation. Only the situation in which the representation was made directly before the death constitutes reason for the absence of the entry in the register at the time of death or shortly after the death.

In the case of minors the objection is made by their statutory representatives and solely during their lifetime; the objection of one representative is effective towards all of the remaining representatives (Article 5 Section 2). The moment the minor attains the age of 16 , he himself has the right to register the objection. The absence of an entry in the central register of objections and the lack of oral representation of a minor

${ }^{46}$ The registered office of the Central Register of Objections is Warsaw. Entries may be verified on the phone or via e-mail by a physician intending to extract the material or a person authorised by them. Following that, there is an obligation to confirm the entry by traditional post (registered mail), Article 6 of the Ordinance of the Minister of Health of $1^{\text {st }}$ December 2006 on the manner of maintaining central register of objections and the manner of verifying entries in the register (Journal of Laws 2006 number 228, item 1671). 
expressing the refusal to grant consent for organ extraction will result in the possibility of extracting cells, tissues, and organs because the legislator did not provide for the possibility to register the objection of statutory representatives after the minor's death. Consequently, statement of intent of the minor's representatives expressing the objection made after the minor's death will not be binding on the physician or other personnel participating in the transplant procedure. Reasonable doubts are raised in relation to possibility of withdrawing the objection, namely, if the objection was made by statutory representative of a minor between 16 and 18, does the minor have the right to withdraw the objection before gaining full capacity to make acts in the law? The legislator has not settled the issue unequivocally. Literal wording of the provision does not exclude the possibility of withdrawing the objection, but it raises doubts whether the scope of authorisation to withdraw the objection may be broader than the scope of authorisation to file an entry in the register of objections ${ }^{47}$.

Practice shows that physicians consult the issue of extraction of biological material with the relatives of the deceased, or de facto ask for their consent. It is quite a frequent situation that due to an objection expressed by the spouse or relatives, even after the patient's death, transplantation procedure is not initiated. There are two apparent problems arising: the difficulty faced by medical personnel and related to holding a conversation on organ extraction ${ }^{48}$ and the need for undertaking social activities aiming at dissemination of knowledge on transplantation ${ }^{49}$.

${ }^{47}$ More on the subject: Joanna Haberko, Izabela Uhrynowska - Tyszkiewicz, Act on procurement, storing and transplantation of cells, tissues and organs. Commentary, Warsaw 2014, Wolters Kluwer, pp. 72-73. Paulina Konarska, "Ex mortuo Transplantation with the participation of a minor donor”, Studia Iuridica Toruniensia, 17(2015): 120.

${ }^{48}$ See: Magdalena Trzcińska, Aleksandra Woderska, Zbigniew Włodarczyk, "Psychological principles in regard to the interview with the deceased donor's family". Anaesthesiology Intensive Therapy, 47(2014): 200-207.

${ }^{49}$ An example of such activity may be the social campaign "Transplantation - I am for! Share Your decision" - educational programme dedicated to secondary school students and realised in chosen educational institutions all over Poland; its objective was to address the subject of transplantology with students and their environment. See: Nina Woderska, "The role of family in making decision on being an organ donor for transplantation", Polish Nursing, 1/47(2013): 7-11. 
The legislator introduced a limitation of the possibility to extract biological material for transplantation if there is a justified reason for suspecting that the death occurred as a result of a prohibited act constituting a crime ${ }^{50}$. In such an event, the extraction may be executed solely after receiving information from the prosecutor that they do not object, and if the proceeding is conducted against a minor - after receiving positive opinion of family court.

The transplantation act does not regulate the requirements for the members of transplantation team. The sole limitation introduced by the legislator is the exclusion from the transplantation procedure of the physician who certified the death of the person whose biological material is to be extracted.

\section{NORWEGIAN REGULATIONS ${ }^{51}$}

Norway is one of the country which introduced the opt in model. The legislator requires a consent for the post mortem extraction of organs. An exception to a consent expressed directly is the situation where the will of the diseased is unknown, in which case the physician's obligation arises to ask the family members of the deceased if the grant their consent for the extraction.

Norwegian legislator drew up one legislative act regulating transplantation of organs from living and deceased donors, autopsy performed in

50 There is no sensu stricto definition of a crime in the applicable criminal code (Journal of Laws of 2016 item 1137 as amended). On the basis of the rules stipulated in Articles 1, 2, 7, and 9, prof Gardocki created a definition of a crime, i.e. an act (action or omission) of a man, which is prohibited by a statute and punishable as felony or misdemeanour, culpable intentionally or unintentionally and detrimental to the society to the extent broader than marginal, see: Lech Gardocki, "The Concept of Offence and the Classification of Offences in Polish Criminal Law", Annales Universitatis Mariae Curie-Skłodowska Lublin - Polonia, Sectio G, LX, 2(2013): 29-30.

${ }^{51}$ Materials for the present part of the article were collected during apprenticeship on biomedical law at the Law Faculty of the University of Bergen financed from Norwegian funds. 
hospital, and organ donation - Lov om transplantasjon, sykehusobduksjon og avgivelse av lik m.m. Special attention should be paid to the selection of legal issues chosen for one legislative act and its length, as only six editorial units are devoted to transplantology. In contrast to Polish regulations, Norwegian act is significantly more laconic, it does not include such detailed regulations with regard to conditions for extraction of biological material or requirements towards the personnel participating in the procedure.

Special attention should be paid to the object of transplantation as Norwegian legislator when referring to transplantations uses the term "organs or other biological material". In spite of this very dissimilarity with Polish regulation which, as it has already been mentioned, uses the term "cells, tissues, and organs", the subject matter of the regulations is identical.

The procurement of organs or other biological material from a deceased donor under Norwegian regulations is possible provided that two prerequisites are fulfilled jointly, i.e. the aim which is the treatment of a disease or a different kind of human body damage and the donor's consent expressed during their lifetime orally or in writing. The obligation of obtaining the consent of a donor during their lifetime is lifted in the situation where organs or other biological material is extracted from a deceased person who died as a result of a disease or was dead on arrival to hospital.

Norwegian legislator excluded the possibility of extracting organs in three cases: if the donor themselves during their lifetime or their closest relative expressed their objection to the procedure; if there exist reasons to suppose that the procurement procedure would be contrary to the donor's beliefs or the beliefs of their closest relatives, or there are other special circumstances constituting counterindications for the extraction. The legislative act in question does not contain a definition of the term "closest relative", nor is there any reference made to a different legal act which would regulate the term quoted. Notably, when taking into consideration the construct of the regulation in question, the legislator did not introduce an obligation on the personnel participating in the procedure to obtain consent of the closest relatives, but only excluded the possibility of extraction in the case of express objection. Thus, the personnel is not obligated to ask all the relatives of the deceased if they object to the procedure, but merely to inform them on the planned procurement. The 
absence of objection should be therefore construed as condition allowing for the extraction procedure.

Similarly as in the case of the "closest relatives" catalogue, the legislator fails to precise what kind of circumstances should be deemed "special" enough to preclude the procedure or which entity should confirm such circumstances. It may be therefore concluded that in the event doubts concerning the possibility of the procurement arise in the course of the procedure, it should be deemed that the procurement is precluded. It will be the entity participating in the procedure that decides whether the doubts are sufficient to terminate the procedure. Hence, the physician classifying a given organ for procurement will be the decisive entity with regard to that organ. The act does not regulate the procedure precluding the procurement or the related documentation. In view of the foregoing, the refusal to extract given biological material cannot be appealed against and with respect to documentation, general rules concerning medical documentation should be applied.

Norwegian transplantation legislative act excludes the possibility of participation in the procurement procedure of the physicians who attending the deceased patient during their last disease. One should consider at this point which of the medical personnel the legislator had in mind. The situation in which the patient dies of cancer does not raise doubts as then the attending oncologist will be excluded from procurement, but what if the person died in an accident? Are the physicians who as the last ones rendered health services to the deceased are to be excluded from the procurement?

Not every centre providing health services is authorised to include transplantation in the scope of their healthcare offer. This aspect also reveals certain differences between Polish and Norwegian regulations. The legislator stated that only the centres which were granted the King's authorisation may be included in the catalogue of entities with the right to perform transplants. The term "transplant" in the context of the legislative act in question refers both to extraction and actual transplantation of the biological material.

As it has been mentioned above, Norwegian regulations are characteristically laconic. The legislator did not provide for non-standard procedure rules except for regulations related to the possibility of extracting an organ 
or other biological material and requirements concerning the personnel confirming death. Under Norwegian law transplantation is not a procedure requiring regulations which would be distinct from standard medical procedures. The fact that organ or other biological material procurement is specific (nomenclature used differs from Polish act which uses the terms "cells, tissues and organs") was the reason why only a few aspects had to be regulated, namely, the rules related to granting consent to extraction, personnel confirming death and the institution which is authorised to perform the transplant.

\section{GIFT LAW MODEL - AMERICAN REGULATIONS}

A solution which meets the opting in model, used in Norway, and opting out, applied in Poland, halfway is the American model, the so-called gift law. Uniform rules of gift law constitute a bridge between the two models discussed. What is more, after analysing the statistics on transplantation in the USA it may be concluded that it is model which fulfils the strategic objective of increasing the number of organ donations ${ }^{52}$. Organ transplantation in its very essence is related to "gift" ('anatomical gifting') - unpaid transfer of biological material from a donor to a recipient. The sole "condition" of the transfer is the donor's death"

The crucial characteristic of the legal construct of gift law is its voluntary nature. Unambiguously expressed intent of the donor to donate organs should be accompanied by appropriate legal regulations. Gift law is based upon total autonomy of the donor. It is the donor, and in the event of their death and in the absence of representation on extraction made

${ }^{52}$ According to data published by U.S. Department of Health \&Human Services the number of living and deceased donors continues to increase: in 2016 there were 15950 donors, including 9971 deceased donors, in 2015 - 15071 including 9079 deceased donors, in 2014 - 14 417, including 8596 deceased donors. The report is available at: https://optn.transplant.hrsa.gov/data/view-data-reports/national-data/\# [date of access: 27.07.2017].

${ }^{53}$ Alexandra K. Glazier, "The principles of gift law and the regulation of organ donation”, Transplant International, 24 (2011): 686, doi:10.1111/j.1432-2277.2011.01226.x. 
during the lifetime - the relatives, who decides on the kind of biological material and the purpose of transplantation ${ }^{54}$.

Gift law is rooted in ownership rights. As any gift, organ donation should meet three criteria jointly: donor's decision, transfer or delivery of the subject matter of donation, and donation acceptance. The respect for the donor's autonomy and the value of their declaration of intent (made in the form of a special document) is expressed in the legal system by the right to extract biological material even in spite of the family's objection ${ }^{55}$. Th requirement of gift acceptance means that from the moment of organ procurement and its transfer to the recipient, the donor, both living and deceased, loses all rights to the subject matter of donation ${ }^{56}$.

As it was mentioned above, there is one legislative act - Uniform Anatomical Gift Act (UAGA) for all 50 states. From the perspective of size and subject matter it is the most extensive document from among the legislative act analysed in the present article. The act contains 27 sections each of which is accompanied by an insightful commentary. Thanks to this form the legislator ensured that the act is more fully and uniformly applied in practice. The commentary forming part of the legislative act enables clarification of the legislator's intentions and better understanding of its provisions (and thus its fuller realisation) both for lawyers and all persons interested in the issue of transplantation, including medical personnel, potential donors and their families.

The nomenclature used in the act is a noteworthy element as the term 'anatomical gift' is employed with the following meaning: "donation of all or part of a human body to take effect after the donor's death for the purpose of transplantation, therapy, research or education". It should be noted that what is stressed in the transplantation is the attitude constituting an expression of altruism and voluntarism as the fundamental basis of transplantation in the USA. The above is also visible in social research, as many as $99 \%$ of Americans are aware of the possibility of organ transplantation and over 75\% would consent to be donors. Research of 1995 showed that on average $85 \%$ of families of the patients qualified to be

\footnotetext{
${ }^{54}$ Ibidem.

${ }^{55}$ Ibidem, p. 369.

${ }^{56}$ Ibidem, p. 370.
} 
donors were asked by medical personnel for their consent to extraction of biological material, and nearly half of them consented ${ }^{57}$. The transplantation act in question introduced a regulation referred to in the doctrine as "required request" laws, which obligates medical institutions to introduce procedures ensuring that families of all patients qualified to be donors are informed of the possibility of donation ${ }^{58}$.

What is more, a whole separate legislative act has been devoted to extraction of a part of a deceased person's body. This area is not regulated in a legislative act together with extraction from a living donor, as is the case in Poland and Norway, or together with organ donation for educational or scientific purposes (Norway). One may therefore consider it to be comprehensive regulation on the subject matter of great importance.

Contrary to Polish and Norwegian regulation, American act provides for the possibility of deciding on procurement both before and after death. During the donor's lifetime there are four types of entities entitled to decide on the extraction an these are: the donor, if minor, it is required they are emancipated or attained the minimum age to receive a driving licence; agent holding a legal empowerment to make decisions related to health matters; the donor's parent in case of a minor donor or a guardian. American legislators took a stance that a minor is mature enough, 17 or older, to drive a vehicle, s/he is also mature enough to make a decision on extraction, especially that the driving licence document may contain the driver's attitude to extraction. A representation made in such a form is tantamount to representation made by an adult. Moreover, there is no requirement of confirming the statement after the minor reaches the age of majority, and it may not be revoked by the parents, even after the minor's death. An emancipated minor is a minor who attained 'the age of majority' maturity due to marriage.

American legislator allowed for the extraction solely for therapeutic, research, and educational reasons. None of those however have been defined in the act. Commentary to Section 4 clarifies that they are defined by their

${ }^{57}$ See: Howard Nathan, Suzanne L. Conrad, Philip J. Held, Keith P. McCullough, Richard E. Pietroski, Laura A. Siminoff, Akinlolu O. Ojo, "Organ donation in the United States, American Journal of Transplantation”, 3(Suppl. 4) (2003): 32.

${ }^{58}$ Ibidem, p. 31. 
common usage in the communities and according to those: Research is a process of testing and observing, the goal of which is to obtain generalizable knowledge, while therapy involves the processing and use of a donated part to provide amelioration or treatment for a disease or condition, and education posits the use of the whole body or parts to teach medical professionals and others about human anatomy and its characteristics. It should be noted that such construct of regulation encompasses also donation of a body or organs for the benefit of educational entities. Moreover, American legislator assumed that the educational purpose may be fulfilled with regard to representatives of other than medical professions.

The forms of making anatomical gift before donor's death are dependent on the person making the declaration of intent. The following are restricted solely for the donor: statement of will or symbol indicating that the donor has made an anatomical gift imprinted on the driving licence or identity card; statement in a will; in the case of terminal illness or injury, by any form of communication addressed to at least two adults, at least one of whom is a disinterested witness. Whereas both donor and other entities may express the will in the following forms: donor card or any record signed by the donor or other authorised person, authorised statement or a symbol indicating that the donor has been entered in the donor registry. The validity of the declaration of intent made in a will or on a driving licence is not influenced by circumstances having impact on the validity of the document, such as for instance: revocation of the licence to drive vehicles or invalidation of the will. If the person making the gift is physically unable to sign the document, the record can be signed by another individual provided that the following conditions are met: at least two adult witnesses, at least one of whom is a disinterested witness; a signed statement of the circumstances of the situation. The latter will apply mostly to a terminally ill donor, who due to their health condition is unable to sign the document confirming their will. The possibility to make a declaration of intent orally is a relatively new institution in American regulations. The statement may also be revoked in the same form. The legislator conditioned the validity of the oral statement on the presence of two witnesses, one of whom needs to be disinterested. Nevertheless, the limited catalogue of persons who under the act, do not meet the criterion of being 'disinterested' raises justified doubts. The catalogue includes 
solely persons related to the donor, i.e. spouse, children, parents, siblings, grandchildren, grandparents, legal guardian, and the donor. The catalogue does not include the partner cohabiting with the donor without marriage, representatives of the medical personnel participating in the transplantation, or persons from the recipient's environment. The mere fact that one of the witnesses does not have to meet the requirement of disinterest raises objections as it allows for influencing the donor's decision and therefore influencing its validity. One may not agree with the solution introduced by American legislators as the regulation in question creates opportunities of abuse opening the door to organ trafficking. The influence which a relative may have on the donor in a terminal state is crucial, yet one cannot preclude the influence of other individuals on the donor's relatives. Even more so, as the patient may remain in a terminal state for a quite long period.

It should be emphasised that American legislators prepared three suggestions for the declaration of intent concerning the extraction of biological material from a deceased donor, each of which gives the possibility to decide on the object and purpose of donation, at the same time not excluding different forms of the document. In the first one the donor represents that $s$ /he grants their consent to donate any needed organs, eyes, and tissue or only selected ones without providing the purpose of the donation. In the second donor card, consisting of three sections, the potential donor indicates the subject of gift (organs, eyes, or tissue) and the purpose for each of those being either transplantation or therapy, research or education, or both. Moreover, the donor may include special instructions and guidelines concerning the biological material donated (section $\mathrm{C}$ ). The third sample donor card is more detailed, the potential donor represents that after their death biological material may be procured for one of the following purposes: transplantation and therapy only, research and education only, or transplantation, therapy, research, and education. The donor further indicates the subject of gift specifying which of the organs and/or tissues may be procured, if not all organs and tissues are to be donated.

The sample donor cards are not the required forms, but constitute a tool popularising knowledge on transplantation and promoting the idea of donation in the society. The legislator's attitude to the consent for transplant is clearly different from the ones presented before. American system allows for a wide range of possibilities of expressing the consent before 
death. It may be claimed that this form is promoted in the legislative act in question. Consequently, the legislator promotes the idea of transplantation and conscious donation in the society.

If a deceased person did not make any declaration of intent concerning potential anatomical gift, post mortem consent for the procurement of eyes, cells or organs is admissible. Under American regulations the group of persons who are authorised to decide both on the subject of gift, as well as on its purpose (transplantation, therapy, research education) is specified. The following persons are authorised to make the declaration of intent are, in order of priority: an agent of the decedent who was authorised to represent the deceased person's interests before their death (provided that the authorisation did not exclude the decisions on transplantation); the spouse of the decedent; adult children of the decedent; parents of the decedent; adult siblings of the decedent; adult grandchildren of the decedent; grandparents of the decedent; an adult who exhibited special care and concern for the decedent; the persons who were acting as the guardians of the person of the decedent at the time of death; and any other person having the authority to dispose of the decedent's body. If there is more than one member of a class entitled to make an anatomical gift, for instance three adult children, the decision of one of them is sufficient. Post mortem declaration of intent should be made in writing or orally, but the oral representation should be electronically recorded or reduced to a record that is signed by the individual receiving the oral communication.

The catalogue of persons authorised to grant consent to procure biological material should be assessed as a good solution. Under American law, the authorisation of a person lower on the list becomes valid solely in the absence of an authorised person of a prior class. Moreover, if there is more than one member of the same class, for instance parents, adult siblings, the consent of one of them is sufficient, and should there be a doubt regarding the attitude of the remaining persons, the consent of all of them is required. The solution requiring joint consent of persons who live in distant locations may be troublesome in practice. The legislator did provide for the possibility to record the statement, yet there is no unambiguous provision stating whether oral consent with the written record of the consent may take place with the use of means of distant communication. When adapting literal interpretation, it may be concluded that such solution is admissible. 
When analysing the construct of catalogue of persons authorised to consent to anatomical gift, it ought to be stated the legislator's aim was to enable the largest number of transplants and not to receive statement of will closest to the deceased person's attitude towards the subject. The primacy of social interest is conspicuous here, the more procurements, the more transplants and opportunities to improve the community's health. While the legislator's assumption should be deemed right, the manner of its implementation is doubtful. Authorising a person who exhibited special care and concern for the decedent or acted as a guardian to make a declaration of intent on procurement of biological material is controversial. There are no requirements concerning the state of awareness and soundness of mind of the patient at the time before death. If what the legislator wanted to achieve was to make sure that the patient has the right to express their last will, it would be reasonable to require that the patient be conscious of their decision. It is challenging to accept that it is a simple negligence on the part of legislators, the more probable reason is to enable the expression of consent for procurement of biological material in a situation where there is no declaration of intent of the deceased who has no family.

The act in question does not regulate the requirements towards the physician or the personnel certifying death. Nor are there any regulations on the choice of applicable regulations - state or federal.

\section{CONCLUSION}

There is a conspicuous difference between the models adopted in Poland, Norway and the USA. As previously mentioned, Polish legislator decided to regulate the rules concerning the consent for procurement according to the opt out model, whereas Norwegian chose the opt in model. Scandinavian legislation imposes on medical personnel the obligation to obtain the donor's consent before death and introduces a ban on procurement if one of the closest relatives of the deceased objects (however, the catalogue of relatives who are entitled to object is not included) or if particular circumstances occur. In spite of differences in the regulations, practice shows certain similarities between the two countries. Polish expe- 
rience proves that physicians, in spite of the lack of statutory obligation, ask the family of the deceased for consent to proceed with transplantation.

The underlying objective of the opting out model adopted in Poland is the increase in the number of cells, tissues, and organs procured. The implied consent construct imposes only the requirement to verify whether the patient expressed their objection before death, yet as practice shows, physicians consult the organ procurement with the family. Public opinion research confirm the assumption that both medical personnel and Polish society are not well prepared for the implementation of the statutory procedure $^{59}$. While transplantology is socially accepted in Poland, it is not the case with procurement without the consent of the decedent's family. Thus, in practice, legislator did not provide for regulations increasing the number of transplantations, but only contributed to the increase of concerns of the society and ambiguous ethical situation of the physicians ${ }^{60}$.

A bridge, or half-way solution between the two European models is American gift law model based on the assumption that donating an organ is the donor's gift to the recipient. What is more, the 'efficiency' of gift law manifests itself not only in social trust towards transplantation in American community ${ }^{61}$, but also in the steadily growing number of donors.

${ }^{59}$ See: Attitudes to Organ Transplantation. Communication on Research number 119/2016, CBOS, Warsaw, 2016; Alina Kośmider-Cichomska, "Attitudes to Organ Transplantation. Report on Research", Warsaw: Ipsos-Demosop for "United for Transplantation" Foundation, 2002, p. 11. See also: Maria Nowacka, "Ethics of Transplantation", In: Bioethics, ed. Joanna Różyńska, Weronika Chańska, Warsaw: Wolters Kluwer, 2013, pp. 221-225. Rafał Kubiak, "Medical law”, Warsaw, C.H. Beck, 2010, pp. 223-224, Katarzyna Białek, "Why do we agree to organ donation? Factors of transplantation decision making)", Pielęgniarstwo i Zdrowie Publiczne, 6(2016): 160. Krystyna Klimaszewska, Anna Baranowska, "Evaluation of social attitudes towards transplantology”, In: Transplantology and transplantological nursing, ed. Hanna Rolka, Beata Kowalewska, Barbara Jankowiak, Elżbieta Krajewska - Kułak, Warsaw: PZWL, 2016, pp. 55-56. Wojciech Boratyński, Paulina Mularczyk, Emilia Sarnacka, "Opinions and attitudes of students of public health to the issues of transplantation medicine", Progress of Health Sciences, Vol 6, No 2 (2016): 200-207.

${ }^{60}$ See: Wojciech Załuski, "An evaluation of the Principles of Contest to Organs Retrieval”, Prawo i Więź, 3(9) (2014): 38-48.

${ }^{61}$ See: R. H. Kuddus, R. S. Mehrizy, A. Minaie, M. A. El-Saidi, A.A. El Ezzi, "Motivation for organ donation among college students in the United States", Transplant Proc., 46(6) (2014): 2046-9, doi: 10.1016/j.transproceed.2014.06.022. Michael Nair-Collins, 
When confronting gift law with the opt in and opt out models, a considerable similarity may be observed. The opt in model requires the donor's consent for organ extraction, yet it reaches out to the idea of informed consent given after acquiring information from a physician, which is not incorporated in gift law. Informed consent is required in the course of treatment, however there is no legislative practice to apply it to decisions after death, for instance with regard to funeral ceremony ${ }^{62}$. At this point the difference between the models is clearly visible, gift law does not impose the obligation of informing the donor, the mere declaration of intent on the gift suffices. In the case of implied consent system, the models partially overlap. There is however a dissimilarity in attitude as in gift law the consent for donation is the donor's gift which means that lack of acceptance on the part of the family does not constitute an impediment to the procurement. The opt in model does not give the donor such extensive autonomy and introduces a possibility of precluding the procurement if the closest relatives object ${ }^{63}$.

Having analysed Polish, Norwegian, and American experience, it is justifiable to conclude that Polish legislator should undertake steps to amend the transplantation act. For the amendment to serve its purpose, which is the increase of organ procurement from deceased donors, it needs to address current problems i.e. it needs to regulate the catalogue of persons authorised to grant consent and precise the obligations of the medical personnel related to the consultations with deceased person's family ${ }^{64}$.

The legislator should provide an extensive catalogue of forms of the donor's declaration of intent confirming the will to donate organs post mortem. Special attention should be paid to the American solution of

Sydney R. Green, Angelina R. Sutin, "Abandoning the dead donor rule? A national survey of public views on death and organ donation", J Med Ethics, 41(4) (2015): 297-302, doi: 10.1136/medethics-2014-102229.

${ }^{62}$ Alexandra K. Glazier, "The principles of gift law and the regulation of organ donation”, Transplant International, 24 (2011): 369.

${ }^{63}$ Ibidem.

${ }^{64}$ Imposing the obligation of consultation will result in modification of education of future medical personnel related to communication with the deceased patient's family. As the article has already shown, the lack of interpersonal skill of physicians in such situations constitutes an impediment to increase the number of organ procurement. 
placing a symbol on identity card. Assuming that the consent to organ procurement post mortem is the donor's gift, it is crucial to regulate the donor's autonomy in relation to the donation. The donor should have the right to decide both about the subject of donation (cells, tissues, selected organs) and the purpose of extraction (therapeutic, didactic, research). The donor's will autonomy is related to the possibility of extracting an organ even when the decedent's family objects.

Furthermore, Polish law should also regulate the situation where the donor did not make any declarations of intent, by imposing a statutory obligation on the personnel to inform on the possibility of organ donation and to ask a relative of the deceased for consent. Indicating authorised persons to decide on the subject may be two-track. On the one hand, the legislator may introduce the institution of a healthcare agent, which is already postulated $^{65}$, who would be authorised to make decisions on the patient's treatment from the moment in which the patient loses consciousness and to decide on the consent for organ procurement. Appointing a healthcare agent should be conditional upon full capacity to make acts in the law. On the other hand, there is the construct of an exhaustive catalogue of relatives which establishes priority in decision-making. It appears justified to stipulate a catalogue analogous to the list of heirs in statutory inheritance ${ }^{66}$, but it is the husband who should have the priority in making the decision. The absence of the spouse's consent excludes the procurement. Nevertheless, a dilemma arises in the situation where the spouse grants their consent and the children, at least one of them, do not. There are two possible solutions in such an event. Assuming the main goal of the regu-

${ }^{65}$ More on the postulate of introducing the institution of healthcare agent to Polish system in: Małgorzata Szeroczynska, Marek Czarkowski, Marek Krajnik and partners, "The institution of health care agent in Polish legislation: position of the Polish Working Group on End-of-Life Ethics”, Pol. Arch. Intern. Med., 2016; doi: 10.20452/pamw.3405; Małgorzata Szeroczyńska, Marek Czarkowski, Małgorzata Krajnik, Romuald Krajewski, Leszek Pawłowski, Anna Adamczyk, Agnieszka Borczak-Oplustil, Piotr Aszyk, Andrzej Kobyiński, Tomasz Pasierski, Piotr Sobański, Iwona Filipczak-Bryniarska, Dariusz Kuć, Anna Orońska, Karolina Smoderek, Monika Lichodziejewska-Niemierko, Wojciech Bołoz, "The institution of health care agent in Polish legislation: position of the Polish Working Group on End-of-Life Ethics”, Practical Medicine, 5 (2016): 102-112.

${ }^{66}$ See: statutory inheritance - Articles 931-940 Act of 23rd April 1964, Civil (Journal of Laws of 2017 item as amended). 
lation is the increase of the number of transplants, the child's objection, when the spouse grants their consent, should not be taken into account. Yet, if the legislator aims at increasing the number of procurements with simultaneous development of social trust towards transplantology, the lack of consent of a close relative, stipulated in an exhaustive catalogue, should preclude the organ procurement. Therefore, a reasonable solution seems to be a regulation containing a catalogue, in order of priority, of persons authorised to grant consent for procurement provided that if any of the authorised persons objects, the objection should be given immediately. In such an event, the objection should be effective.

To conclude all the considerations presented in the article, a postulate de lege ferenda of amendment to Polish transplantation act needs to be made in order to introduce the gift law model into Polish legal system. However, for the amendment to achieve its fundamental objective, which is the increase of the number of post mortem procurements, it cannot be a mere reproduction of the regulations by a different legislator as is presently the case, but it must be adjusted to Polish society. That is why the regulations should be accompanied by social campaigns promoting the consent for organ donation in the form of donor's gift.

\section{REFERENCES:}

Antkowiak, Paweł. 2013. "Polish and European standards of performing independent professions", "Politology Review", 1: 135.

Bennett, Mia. 2008. "Icy/Hot: Norway and Finnish Policy toward the European Union", Claremont: UC Undergraduate Research Conference on the European Union, Vol 2008, article 3, DOI: 10.5642/urceu.200801.03 available at: http://scholarship.claremont.edu/cgi/viewcontent.cgi?article=1014 \&context=urceu.

Białek, Katarzyna. 2016. "Why do we agree to organ donation? Factors of transplantation decision making)", "Pielęgniarstwo i Zdrowie Publiczne", 6: 160.

Boczek, Michał. 2016. "Transplantation of business", In: New medical procedures vs law, ed. Sobczak, Jacek, Reshef, Magdalena. Toruń: Adam Marszałek Publishing House. 
Boratyński, Wojciech, Mularczyk, Paulina, Sarnacka, Emilia. 2016. "Opinions and attitudes of students of public health to the issues of transplantation medicine", "Progress of Health Sciences:, 6(2): 145.

Buczyński, Szymon, Snopek, Paweł. 2013. "Criminal aspects of illicit trafficking in human organ, tissues and cells", "Hygeia Public Health", 49(2): 229-234.

Czyż, Kamil. 2007. "Civil society as the prerequisite of democratic state", "ZNZE WSIiZ”, 1(3): 175-197.

Dal Sasso Mendes, Karina, de Aguiar Roza, Bartira, de Fatima Faria Barbosa, Sayonara, Schrimer, Janine, Maria Galvao, Cristina. 2012. "Organ and tissue transplantation: responsibilities of nurses", “Text Context Nursing”, 21(4): 946.

Dubowski, Rafał. 2017. "Non omnis moriar. Organ Procurement for transplant under Spanish law against the background of Polish law", In: Nasciturus pro iam nato habetur: on protection of conceived baby and the mother, ed. Gołaczyński, Jacek, Mazurkiewicz, Jacek, Turłukowski, Jarosław, Karkut, Daniel. Wrocław: Wydział Prawa, Administracji I ekonomii Uniwersytetu Wrocławskiego Oficyna Prawnicza.

Duda, Juliusz. 2011. Medical Transplantation Issue Viewed from the Civil-Law Perspective. Warsaw: Wolters Kluwer.

Gałkowski, Jerzy W, Kanafa, Łukasz. 2010. "Civil Society and Morality”, "Annales Ethics in Economic Life", 13: 69-75.

Gardocki, Lech. 2013. "The Concept of Offence and the Classification of Offences in Polish Criminal Law", "Annales Universitatis Mariae Curie-Skłodowska Lublin - Polonia, Sectio G”, LX, 2: 29-30.

Glazier, Alexandra K. 2011. "The principles of gift law and the regulation of organ donation", Transplant International, 24: 686. doi:10.1111/j. 1432-2277.2011.01226.x.

Głogowska, Anna. 2013. "Trafficking in persons for the purpose of organ removal from an international legal perspective", "Białostockie Studia Prawnicze", 13: 137-145.

Guzik-Makaruk, Ewa Monika. 2008. Organ, tissue, and cells transplant in legal and criminological terms, Białystok: Temida 2.

Haberko, Joanna, Uhrynowska - Tyszkiewicz, Izabela. 2014. Act on procurement, storing and transplantation of cells, tissues and organs. Commentary, Warsaw: Wolters Kluwer.

Haberko, Joanna. 2009. "Current medical knowledge and using homeopathy", "Medyczna Wokanda”, 1: 47-59. 
Haberko, Joanna. 2011. "A few comments on ex mortuo tissue, cell, and organ extraction from foreign donors", "Medyczna Wokanda", 3: 102.

Haberko, Joanna. 2012. "Applying techniques of medically supported procreation not only for parental purposes. The problem of 'baby-biological resupply vehicle", "Wokanda Medyczna", 4: 31-43.

Hołub, Grzegorz. 2009. "About two ways of acquiring organs for transplantation”, "Studia Gdańskie”, XXV: 129-146.

Jasudowicz, Tadeusz. Czepek, Jakub, Kapelańska - Pręgowska, Julia. 2014. International Bioethics Standards. Documents and judicial practice, Warsaw: Wolters Kluwer

Jurek, Joanna, Chwal, Martyna, Janusz, Bernadetta, de Barbaro Bogdan. 2011. "Organ Extraction post mortem: psychological situation of the family, cultural context, the role of professionals (Family context of decisions on the deceased relative's organ donation. Research review)", "Psychoterapia", 4 (159): 51-64.

Klimaszewska, Krystyna, Baranowska, Anna. 2016. "Evaluation of social attitudes towards transplantology", In: Transplantology and transplantological nursing, ed. Rolka, Hanna, Beata Kowalewska, Barbara Jankowiak, Elżbieta Krajewska - Kułak, Warsaw: PZWL, 2016.

Konarska, Paulina. 2015. "Ex mortuo Transplantation with the participation of a minor donor", Studia Iuridica Toruniensia, 17: 120.

Konarska, Paulina. 2016. "Post mortem extraction and transplantation of organs, tissues, and cells in Asia exemplified by Singapore and India - selected aspects", "Studies in Law: Research Papers", 1(18): 142-144.

Konarska, Paulina. 2016. "Post mortem extraction and transplantation of organs, tissues, and cells in Asia exemplified by Singapore and India - selected aspects", "Studies in Law: Research Papers", 1(18): 142-144.149

Kośmider-Cichomska, Alina. 2002. Attitudes to Organ Transplantation. Report on Research, Warsaw: Ipsos-Demosop for "United for Transplantation" Foundation.

Krasnowolski, Andrzej. 2013. Professions of Public Trust Regulated Professions and Independent Professions. Origins, functioning and current problems, Warsaw: Chancellery of the Senate, Thematic Papers OT-625.

Kubiak, Rafał. 2010. "Medical law". Warsaw: C.H. Beck.

Kuddus, R. H., Mehrizy, R. S., Minaie, A., El-Saidi, M. A., El Ezzi, A.A. 2014. "Motivation for organ donation among college students in the United States", Transplantation Proceedings, 46(6): 2046-9. doi: 10.1016/j. transproceed.2014.06.022. 
"Lexicon of Medical Law. 100 basic terms", ed. Adam Górski, Warsaw: C.H. Beck, 2012, p. 237.

Lindsell, Jonathan. 2015. The Norwegian Way. A case study for Britain's future relationship with the EU, London Civitas: Institute for the Study of Civil Society

Maj-Waśniowska, Katarzyna. 2015. "Dilemmas of civil society in Poland", "Research papers of Wrocław University of Economics", 404: 170-189.

Nair-Collins, Michael, Green, Sydney R., Sutin, Angelina R. 2015. "Abandoning the dead donor rule? A national survey of public views on death and organ donation”, Journal Medical Ethics, 41(4): 297-302. doi: 10.1136/ medethics-2014-102229.

Nathan, Howard, Conrad, Suzanne L., Held, Philip J., McCullough, Keith P., Pietroski, Richard E., Siminoff, Laura A., Ojo, Akinlolu O. 2003. "Organ donation in the United States", "American Journal of Transplantation", 3(Suppl. 4): 32.

Nestorowicz, Mirosław. 2007. „Medical Law”, Edition VIII, Toruń: Towarzystwo Naukowe Organizacji I Kierownictwa.

Nowacka, Maria. 2013. "Ethics of Transplantation”, In: Bioethics, ed. Joanna Różyńska, Weronika Chańska, Warsaw: Wolters Kluwer.

Olejniczak, Elwira, Beata Kukiela. 2012. "Media image of ex mortuo transplantation and legal regulations", "Folia Linguistica", 46: 86.

Paszkowska, Małgorzata. "Legal admissibility of transplantation as a method of treatment" "Review of Rzeszów University and National Medicines Institute in Warsaw", 4: 546

Paszkowska, Małgorzata. 2011. "Legal admissibility of transplantation as a method of treatment", "Medical Review of Rzeszów University and National Medicines Institute in Warsaw", 4: 546

Rowiński, Wojciech. 2011. "Legal, ethical, social, and organisational aspects of organ transplantation in Poland (Data as of the end of 2009)", In: Public Health. Selected Aspects. Vol. II, ed. Janusz Opolski, Warsaw: Medical Postgraduate Training Centre.

Rzepliński, Andrzej. 2002. "Legal limits of human organ and tissue transplantation admissibility under the provisions of the European Council", "Prawo i Medycyna:, 2(12 vol. 4).

Sarnacka, Emilia. 2016. "Legal aspects of transplantation”. In: Transplantology and transplantological nursing, ed. Rolka, Hanna, Beata Kowalewska, Barbara Jankowiak, Elżbieta Krajewska - Kułak, Warsaw: PZWL, 2016. 
Sasinowski, Henryk. 2012. "Civil society and its role in the creation of democracy", "Economy and Management" 1: 33.

Szeroczyńska, Małgorzata, Czarkowski, Marek, Krajnik, Małgorzata, Krajewski, Romuald, Pawłowski, Leszek, Adamczyk, Anna, Borczak-Oplustil, Agnieszka, Aszyk, Piotr, Kobyiński, Andrzej, Pasierski, Tomasz, Sobański, Piotr, Filipczak-Bryniarska, Iwona, Kuć, Dariusz, Orońska, Anna, Smoderek, Karolina, Lichodziejewska-Niemierko, Monika, Bołoz, Wojciech, 2016. "The institution of health care agent in Polish legislation: position of the Polish Working Group on End-of-Life Ethics", "Practical Medicine”, 5: 102-112.

Szeroczynska, Małgorzata, Czarkowski, Marek, Krajnik, Marek and partners: "The institution of health care agent in Polish legislation: position of the Polish Working Group on End-of-Life Ethics”. “Pol. Arch. Intern. Med.”, 2016. doi: 10.20452/pamw.3405

Tokarczyk, Roman. 2000. "Outline of regulation on human organs transplantation”, Legal, Economic and Sociological Movement, LXII(1): 20.

Trzcińska, Magdalena, Woderska, Aleksandra, Włodarczyk, Zbigniew. 2014. "Psychological principles in regard to the interview with the deceased donor's family". "Anaesthesiology Intensive Therapy", 47: 200-207.

Woderska, Nina. 2013. "The role of family in making decision on being an organ donor for transplantation", "Polish Nursing", 1(47): 7-11.

Wróbel, Aleksander. 2016. "Comparative law studies in criminal law on the basis of criminal law system in Poland, Ukraine, and Russia - From theory to practice", "Scientific Papers of Jagiellonian University PhD Students Association. Social Sciences", 15(4): 264.

Załuski, Wojciech. 2014. "An evaluation of the Principles of Contest to Organs Retrieval”, "Prawo i Więź”, 3(9): 38-48. 
